\title{
The Relativistic Theory of Coincidence between Mens Rea and Actus Reus in Islamic and English Law
}

\author{
Ali Saffary $^{1 *}$, Razieh Saberi ${ }^{2}$ \\ ${ }^{\mathrm{T}}$ Faculty of Law, Shahid Beheshti University, Tehran- Iran \\ ${ }^{2} 4$ th Unit, No 14, Malaek 1 st Alley, Kohestan Blvd, Ketab Sq, Saadat Abad, Tehran- Iran
}

\section{Article History}

Received: 03.09.2020

Accepted: 24.09 .2020

Published: 06.10.2020

Journal homepage: https://www.easpublisher.com/easjhcs

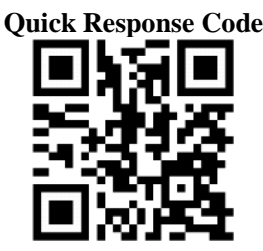

Abstract: Coincidence between mens rea and actus reus is a main principle of criminal law. The accepted wisdom, in all legal systems, is that the mere existence of mens rea and actus reus does not suffice to bring into its legal identity any crime requiring both elements, so their simultaneity is also necessary. The necessity of coincidence between the two in its exact literal meaning of the word has been justified by different reasoning which has led to an "absolute" account of the principle. Although the acceptance of this account has a number of positive effects, it could cause negative effects and injustice too. The objective of this study is to explicate a different reading of the principle, by which the criminal justice system can be freed from the trap of such negative effects. Our rival reading of the principle may be termed the "Relative" as opposed to the "Absolute or traditional" approach. While the latter i.e. the "traditional or absolute" account of the principle reads that the coincidence of elements in relation to all crimes requiring both material and spiritual elements must absolutely exist at point (1) of the time axis of the process of commission, the former, i.e. our "Relative" account of coincidence reads that coincidence between elements may occur at any point, for instance $\left(\frac{1}{2}\right)$ of the time axis, for a better understanding of which a graph of different states of relativity of coincidence is prepared. As it is argued here, the "traditional or absolute" approach to the concept of coincidence creates a number of obstacles for the justice system to serve justice for all. Using our new approach however, it is argued here, would minimize the injustice caused by the traditional approach of coincidence as much as possible, serves the victim's interest and public order much more comprehensively.

Keywords: Coincidence of mens rea and actus reus, Absolute account, Relative approach, The rule of "Al-emtena", The rule of "a single sequence of events".

Copyright (C) 2020 The Author(s): This is an open-access article distributed under the terms of the Creative Commons Attribution 4.0 International License (CC BY-NC 4.0) which permits unrestricted use, distribution, and reproduction in any medium for non-commercial use provided the original author and source are credited.

\section{INTRODUCTION}

Maintaining social expediency" is known to be the most fundamental element influencing the process of emergence, transformation, and evolution of law in general and the criminal law and its related institutions in particular. It is undeniable in the process of social changes and developments to properly and accurately identify their underlying social necessities and, as far as possible, to avoid the extremist and rejected approach to the scientific and practical capitals of the past and focus to positive prospects and capacities of their future. By the same token, it seems that criminal law is also one of the areas where the emergence of social necessities is inevitable. This requires a deep account of the legacy of the past, as well as focusing on the new social needs to understand and properly apply legal principles. It means that the principles and rules governing the criminal law have developed out of such dynamic interaction between social exigencies and new needs as to be able to solve the new problems with an approach consistent with its long-standing tradition.

Similarly, social expediency can be taken to explain the nature and logical basis of our main argument in this article, that is the relative approach to coincidence between mens rea and actus reus. This new approach is in contrast to the traditional and classical, i.e. the absolute approach to the principle. Transformation as such in our attitude to a legal concept as the principle of coincidence seems to be inevitable in the light of social changes and developments. 
The topic that is studied in this article in the light of such new legal developments is the necessity to review, both in theory and practice, the principle of coincidence between mens rea and actus reus in crimes where their coexistence is vital. The study of the subject indicates that no in-depth analysis has been essentially made of it, both in theory and practice. This has caused serious doubts in the proper application of the rule when and where the issue at stake in an individual case is coincidence of elements. Apart from a few studies that have often been conducted in terms of theoretical principle of the necessity of coincidence between the elements, its practical application, as a subject, has not been considered.

As far as our review goes, the existing wisdom indicates that in all legal systems including written and unwritten laws, there should be coincidence between the two, i.e. material and spiritual elements of a crime. Coincidence occurs in three forms: The balance between mens rea and actus Reus, correspondence between the two elements and coincidence or simultaneity between the two elements [1].

Based on the principle of coincidence or the simultaneity between elements, the mere existence of the two elements does not suffice in crimes requiring both mens rea and actus reus, but their simultaneity is also necessary in the absolute verbal meaning of the term, coincidence. This is what we term absoluteoriented view of coincidence which we believe would sometimes cause injustice. This would occur in two situations: 1- where the spiritual element would occur prior to material element of a crime in the state of unconsciousness or consciousness; 2- where material element precedes the spiritual element. Our suggestion is that a different reading or perception of the concept of coincidence i.e. the relative reading would help to avoid such injustices, while the rule maintains its vital position as main legal rule.

In the absolute-oriented conception, as a classical and traditional account of coincidence between elements, no reservation is justified in order to include cases in which coincidence between the two elements has not been satisfied in its full verbal meaning of the term. In other words, the absolutist approach is based on an absolute verbal standard for the coincidence of mens rea and actus reus. Relying on this, the existence of coincidence between mens rea and actus reus and, consequently, conviction and sentencing of the offender is merely acceptable in either true or false states. This may be fulfilled regardless of whether such a notion brings justice to the criminal system or, on the contrary, leads to injustice.

\footnotetext{
1. Simester \& Sullivan, Criminal law: Theory and Doctorin, 160-170.
}

Despite the possibility of causing clear injustice, this view of coincidence is not baseless. It has attracted different philosophical and legal justifications such as justice in the criminal law, respect for human dignity, the moral responsibility of the offender and his/her punishment, accordingly. The acceptance of this absolute account of the principle of the coincidence between mens rea and actus reus has positive implications, too. These include the delinquent right for punishment, the effectiveness of punishment and the legitimacy of punishment. Hence, if a person, despite the lack of coincidence of mens rea and actus reus and just due to the mere presence of these two elements is convicted and punished, neither justice has been met, nor the punishments would be counted commensurate to the crime committed. More importantly, no benefit would be gained for the community from the execution of such an unjust punishment.

Despite strong philosophical and legal foundation of the principle of coincidence between mens rea and actus reus and the resulting positive effects, the absolute view of coincidence in some cases leads to injustice in the criminal system such as unfair discrimination, escaping dangerous offenders from punishment, neglecting the interests of the community and the right of the victim. These injustices and their negative effects have led legal scholars and jurists of the Islamic and common law legal systems to make a number of efforts to find new solutions to get rid of these injustices, in applicable cases, by arguing differently and, in our understanding, discarding the absolute view of the principle and to resort to a new perspective of coincidence between the elements. This long-standing, yet in our view ignored account of coincidence, is termed the relative approach of the rule in question.

In fact, the criterion of the value of coincidence between mens rea and actus reus is the rate of goodness and benefit created to achieve justice as the ideal of all criminal justice systems. Our view of relative approach to coincidence of mens rea and actus reus, we would argue, can more conveniently be justified. In this perception of coincidence, the fulfillment of condition of coincidence of the elements of the crime and, consequently, the criminal liability is established on a multi-state and fluctuating oscillatory axis, similar to the axis of numbers, instead of a twomode axis. These fluctuating states or relativeness of the coincidence are determined according to the nature of the criminal act and necessities or expediencies found at any time period and at any given situation to achieve the ultimate goal of justice. In this way, neither the principle of coincidence is violated nor will the lawmakers and the lawyers have to make isolated and sporadic arguments in any particular case. Rather, by referring to the relativity of coincidence between mens rea and actus reus and, as the case may be, coincidence 
of the intention and the act in a part of the action or its preliminary parts, the person can be assumed responsible for his actions.

In other words, justice is an absolute moral concept to which, no constraints and conditions are applied in order to materialize justice in its true sense. In contrast, coincidence of mens rea and actus reus, as one of the pillars of fulfilling criminal liability contrary to the concept of justice, is not found on a moral proposition, but rather it is a concept derived from social expediency which help society to achieve justice. Since according to the circumstances and situations, social expediencies may change, the form of the coincidence between mens rea and actus reus changes too. Therefore, this concept, namely, coincidence of elements, is a relative concept so following any changes and developments in its form due to its relative nature, may better guarantee justice as an absolute moral concept. This is because if coincidence of mens rea and actus reus is supposed to be an absolute concept which does not change in accordance with social expediencies in the circumstances and situations, it will lose its function and cannot serve justice anymore.

Our theory of relativism of coincidence between the two elements, as in any other newly established theory, requires proving to consolidate its bases in the world of law. Hence, in this article, it is attempted to explicate the legal foundations of this new theory, as it is exemplified by English and the Iranian Islamic legal system. The main and core argument of our new approach is based on a rule in Islamic jurisprudence known as the rule of "Al-emtena o Belekhtiar La-yonafi Al-ekhtiar[2]", on the one hand, and on the rule of "One transaction or a single sequence of events" in English common law system. This rule is, in turn, based on two concept of "prior fault" and "continuing act".

An examination of these rules helps to clarify and better understand the claims of the present article, i.e. the relative account of coincidence between mens rea and actus reus. Our claim, while respecting the principle of coincidence in criminal matters, makes it possible to maintain justice and order, as well as, to better ensure and guarantee them as the supreme goals of the criminal system. It is argued here that, the two principles, the rule of "Al-emtena" and the rule of "a single sequence of events" provide a solid and acceptable justification for the responsibility of the individual where there is no apparent or hundred percent coincidence between the act and the intention of the perpetrator

There are different cases where lack of coincidence is apparent, including "the primacy of the

${ }^{2}$. From now on, for convenience "Al-emtena" is used. mental element on material" or "the primacy of the material element on mental" occurs. Primacy of the mental element on the material takes place where the offender is sober or where unconscious. In each of these scenarios, it can be argued that in spite of lack of apparent coincidence in its rigid and literal meaning the word (lack of coincidence based on the absolute viewpoint) justice and fairness require that the offender is taken criminally responsible for the crime committed. In the case of the priority of the mental element on the material where the offender is in the state of consciousness, if the previous fault was based on the theory of "prior fault", one can use the rule of "a single sequence of events" in order to justify and secure criminal responsibility and conviction for the offender. With the same logic, if the material element is preceded on the mental element and if the criminal act is continually persisted, based on the theory of "continuing act", one can refer to the rule of "a single sequence of events" to secure criminal responsibility for the offender. In both of the following sections, each of these two principles and their relationship with our theory of "relative coincidence between elements" are discussed in detail.

\section{The rule of "Al-emtena" and relativism of coincidence}

According to the jurisprudential literature, whenever a legally liable person is compelled by his/her own voluntary action or discretion to fell in a state of mental insufficiency, during which he/she commits an intentional crime, s/he is criminally liable as such, although s/he apparently does not understand the nature of his/her own illegal behavior. In other word, such a behavior will be considered voluntary and, it is subjected to its legal consequences, i.e. criminal liability and punishment. This legal state is discussed in jurisprudential, hermeneutics and theological books under the title of the rule of "Al-emtena" which is based on human reason or wisdom, as one of the Islamic sources of law[3].

The principle of "Al-emtena" is normally studied in the science of principles of Fiqh (Usul alFiqh) under the title of intellectual affiliation. It is also one of principles of Fiqh [4] as well as a legal maxim. Due to the close connection between these two branches of Islamic sciences, some of the scholars have described it as a jurisprudential-hermeneutics principle. The Shi $i$ jurists believe that according to the rule of "Al-emtena", when a person does a voluntary act which enters him/her into another illegal, albeit apparently involuntary criminal activity, then he/she cannot stand on the defense of involuntariness. In such a case the offender is not considered to be compelled to do so involuntarily, but $\mathrm{s} / \mathrm{he}$ is taken liable for his/her prior

\footnotetext{
${ }^{3}$. Eshtehardi, Madark Al Orvah, 34.

${ }^{4}$. Mostafavi, Maate ghaedate Feghieh, 69.
} 
voluntary exercise of his/her intention to create such a state of involuntariness.

Simillarly, jurists and scholars of other countries such as France seems to refer to the rule of "Al-emtena" where and when they make use of a legal rule entitled "an act of optional cause". According to this legal rule, if a perpetrator initiates the offense voluntarily, s/he will also be liable for the result, although unintended [5].

Islamic scholars and lawyers have, in many cases, accepted full criminal and civil liability for the offender, according to the rule of "Al-emtena". Necessity is one of the areas where the rule of "Alemtena" is alluded to. Islamic jurists believe that if someone with his/her own discretion brings about an urgent situation where an illegal (religiously illegitimate) or criminal behaviour is necessitated, he cannot take advantage of the defence of necessity and escape liability and thus deserves punishment, because he was the cause of acting in such a state of necessity. In fact, the rule of "Al-emtena" is an exception to the general rule of necessity which removes punishment only if a voluntary act of the perpetrator was not the cause of the state of necessity[6]. Self-defense is also another area where the use of the "Al-emtena" is observed. Lawyers state that if a crime is committed by deliberate provocative act of the victim, then the victimization is the direct result of his/her voluntary behaviour. In such a case, the victim cannot repel the offender by force and then resort to self-defence in order to escape criminal liability and punishment based on the principle of "Al-emtena", since the offense was resulted from his/her own prior voluntary behavior[7].

In legal and jurisprudential text books, another application of the rule of "Al-emtena" is discussed where ignorance or mistake of law is at stake. Regarding the elimination of responsibility and punishment where ignorance of law, most scholars believe that if ignorance does not derive from offender's fault, criminal responsibility will be ruled out. However, if $s /$ he is reckless or intending not to know the law, then according to the rule of "Al-emtena", criminal liability and the legal punishment will not be taken from him[8].

The rule of "Al-emtena" therefore has various uses in the writings of Islamic scholars and Iranian jurists; but the most famous application, which is proof of our theory of relativity of the principle of coincidence between elements, is the application of this

\footnotetext{
${ }^{5}$. Mostafa, Description of the law Al Oghoobat, 425.

${ }^{6}$. Rahmani Zarvandi, The rules of jurisprudence (3) (The rule of emergency), 2.

7 . Ardebili, General criminal law, 294.

${ }^{8}$. Khoei, Fundamentals of Takmelah Al Menhaj, 169.
}

rule to murder by a drunk or an asleep. All jurists agree[9] that where a crime of murder is committed by an asleep who knows will commit the crime if fells asleep, or it is committed by an individual who voluntarily becomes drunk to commit murder, based on the rule of "Al-emtena", the murderer has full criminal liability and will be punished accordingly[10].

Some lawyers [11] have provided several reasons to justify criminal responsibility of a drunken person who has drunk voluntarily to commit a crime. These scholars believe such a drunken person will have full criminal responsibility because, first, the person in question deliberately chose to drink for committing a crime and used his right to choose to commit a crime; therefore, he deserves to be blamed and punished. Second, it is true that the person has committed the crime while intoxicated, but this person knowingly has deprived himself of his liberty and is like someone who voluntarily chooses to commit a crime. Third, the exemption of such a person from punishment not only does lead to the victim being ignored, but it also causes people to be encouraged to drink and commit a crime while drunk, hoping to be exempted from punishment. This is definitely contrary to the interests of the community.

A point in relation to intentional murder by such a drunken person and its punishment that has to be mentioned here is that although the required mental element of murder exists before the offense is committed; the drunk has no intention and consciousness during the commission of the material element. So apparently there is no concurrency between the two elements based on the absolute view of the principle of coincidence and it is not possible, in principle, to convict such a person to deliberate killing and its legal punishment. However, this defense has not been accepted by Islamic scholars and lawyers. They argue that the rational principle of "Al-emtena" permits punishing such a murderer, because the offender has chosen and decided freely to lose his intention, thus s/he has to accept its consequences too[12]. Therefore, it can be concluded that the theory of jurists and lawyers in

\footnotetext{
9. Movahedi Lankarani, Comprehensive Issues, 452; Marashi Najafi, Al-Qasas Ali Zoe Al-Quran and AlSunnah, 444-431; Makarem Shirazi, New Esftaat, 430; Najafi, Javaher Al-khalam Fi Sharh Shariah Al-Islam, vol. 21, 92-90; Madani Kashani, Book of Al-Qasas Lel Foghaha v Al-Khawas, 105-103; Sabzevari, Mohzzab al-Ahkam, 176.

10. Montzeri Najafabadi, Islamic government jurisprudential principles, 207.

11. Ali Abadi, Criminal law 192; Aghaei Nia, Crimes against individuals, 138; Aghaei Janat Makan, General Criminal Law, 147.

12. Ismailian, "Drunk Qisas in Imam jurisprudence, relying on Kheoi's researcher", $40 \& 42$.
} 
this regard is consistent with the relativistic approach to coincidence, and in fact, they followed it without specifying this approach.

Similarly, Islamic jurists, in principle, state that there is no responsibility regarding an offense committed by a sleeping person. Therefore, if a person while sleeping injures another, by motions of his/her hands or feet, the offense committed as such is involuntary and lacks a mental element, so there is no punishment [13]. Despite this general rule, where the same jurists discuss the responsibility of a person who drinks voluntarily to commit a crime when intoxicated, stress that according to the rule of "Al-emtena", a person who knows if sleeps will commit a crime, is responsible and punishable as an awake offender[14]. By the same token, lawyers believe that a sleep-walker who is aware of his/her sleep-walking abnormality and knows that may kill or injure his/her friend sleeping next to him/her and, nevertheless does not take any step to prevent such an offense, is fully responsible and punishable as such, according to the principle of "Alemtena". This is so despite the fact that coincidence between the two material and mental elements of the crime committed as such does not exist in its absolute or literal meaning [15].

The fact is that relying on the rule of "Alemtena" in such cases is in apparent contradiction with absolute view of the coincidence of material and mental elements. This line of thinking, based on the rule of "Al-emtena" seems, however very useful in the sense that it appears to better maintain the public order and security of the community, as well as to fully support our theory of relativity of the principle of coincidence between the two elements of a crime. This paves the way for a more practical understanding of criminal law to maintain justice if the circumstances of a case require. It could be argued that the ratification of articles 153 and 154 of the Islamic Penal Code of Iran 1392 in full accordance with the rule of "Al-emtena" is one step forward to avoid the undesirable consequences of the absolute account of the principle of coincidence between the two elements, most notably injustice in the criminal system. In fact, such an approach to the principle of coincidence between mental and material elements of a crime based on the principle of "Alemtena" challenges the traditional and absolute view of

\footnotetext{
13. Yektan khodaei, "Drunkenness and Sleep and anesthesia as Causes of elimination of responsibility", 45.

14. Mohaghegh Heli, Sharaie Al-Islam Fi Masael AlHalla and Al-Haram, 201; Marashi Najafi, Op. cit., 444; Tabrizi, Tanqih mabani Al-ahkam - Book of AlQasas, 162-160; Khansari, Jame Al-Mardak Fi Sharh Al-Mokhtaser Ah-Manafe, 190.

15. Gapanchi, "The Qisas of the drunken killer in Islamic Jurisprudence and Islamic Penal Code", 80.
}

coincidence and makes the acceptance of our relativistic account of the principle inevitable. This is because in the former view, one has to justify liability and punishment on an artificial reasoning to avoid injustice in such cases where coincidence in its rigid meaning of the concept of coincidence does not exist, but in the latter account a more logical, consistent and acceptable justification is provided which is in full harmony with all legal rules and social necessities.

In this section, it became clear that jurists, lawyers, and even the legislature accept criminal responsibility in cases such as sleepwalking and intentional drunkenness for committing a crime based on the rule of "Al-emtena". By principle, this is not possible except by a relative view of the coincidence of actus reus and mens rea; otherwise, it cannot be claimed that the rule of coincidence has been observed. In the next section, another legal rule is analyzed, which, as in the "Al-emtena" rule, supports our relative view of the principle of coincidence. This rule of common law is known as the rule of "a single sequence of events of the act" which is based on the two concepts of "prior fault" and "continuing act".

\section{The rule of "a single sequence of events" and the relativism of coincidence}

In criminal law of common law systems, as in the Iranian Islamic system, one of the general principles governing criminal law is the principle of coincidence of material and mental elements of a crime. In other words, the mental or fault element must coincide in time with the criminal behavior or the material element of the crime. According to this principle, a vital issue for the court is to determine whether the perpetrator was intending while performed the forbidden behavior and as such deserves a sentence [16]. However, this is not always as easy it may seem to be, since the absolute application of the principle of the coincidence of actus Reus and mens rea has brought problems and challenges. For instance, in a case where A hits B on the head not knowing he is whom A was intending to kill since long time ago, but when he finds out B needs medical care to survive does not take any action to save B's life. Apparently, there is no coincidence between the hit on B's head by a and his intention to see B dead. Another example is that A hits B on the head believing he is dead. Then, in order to get rid of the body puts it on fire and later it is found that the death was caused by fire (when A was not intending to kill B) but when A hit B on the head he was not killed. In this case, too, coincidence between the forbidden hit on the head and intention to kill does not exist in its rigid meaning of the term. However, it appears unjust to leave such killings unpunished in both cases.

\footnotetext{
${ }^{16}$. Ashworth \& Horder, Principles of criminal law, 94, 165.
} 
In order to overcome such states of injustice and its challenges for the criminal system, common law system has invented a general rule entitled "a single sequence of events"[17]. This rule is studied in the following two sections, first a review of legal literature by British and Iranian-Islamic scholars is offered. Then, the application of the rule in practice is analyzed.

\section{Academic literature}

The rule of "a single sequence of events" reads that where material element of a crime is constituted of different sequence of acts and the intention of the criminal is found to be present at any point of these events leading to the resulted crime, then the condition of coincidence of the material and mental elements has been met[ 18 ]. Under this rule, two independent situations have been discussed: firstly, mental element takes place before the material element where, coincidence is accepted according to the theory of "prior fault. Secondly, material element takes place prior to mental element, in which case, coincidence is assumed to exist between the two elements based on the theory of "continuing act"[19].

Both theories underpinning the rule of "a single sequence of events" are serious challenges of the absolute account of the rule of coincidence between the elements and, at the same time, consolidate our theory of relativism. In other words, both theories of "prior fault" and "continuing act" express the fact that absolute coincidence in all cases appears undesirable and problematic that leads to instances of injustice to the victim and undermines public order.

Based on this theory, if an illegal event, whether criminal or civil, was caused by the former fault or the conditions that the offender him/herself deliberately created, s/he cannot make use of the defenses such as intoxication, coercion, drunkenness and the like[20]. The two most important and practical examples of such a situation include:

1- One intentionally tries to increase his courage to commit a certain criminal behavior by way of deliberate intoxication.

In this case, the reason why the offender cannot resort to the defense of intoxication is because

\footnotetext{
17. Herring, criminal law Concentrate, 35-36.

18. Mir Mohammad Sadeghi, Crimes against individuals, 317.

19. Child, Ormerod \& Smith, ormerod's Essential of criminal law, 136-141; Findlay, Criminal law: problems in context, 130; Elliott \& Quinn, Criminal Law, 26.

${ }^{20}$. Robert Cryer et al., An introduction to international criminal law and procedure, 407.
}

the resulting incident is due to his previous fault [21]. For example, in the suit of the (A. G. for Northern Irland V. Gallagher), the defendant decided to commit a criminal act and, in order to dare himself, drank alcohol. His drunkenness did not exempt him from punishment, although it is legally, in its rigid legal meaning of the term coincidence, impossible to say that the mind and the act of the offender or, in other words, the mental and material elements of the crime committed were coincided[22].

2- Someone deliberately provokes another against him/her to attack him/her and then defends against that attack [23].

In this case, too, the perpetrator cannot rely on self-defense [24] because s/he provoked the attack, i.e. his/her previous fault is the main cause of the attack.

In each of the two examples above, if the routine or absolute approach, to the principle of coincidence is taken, then it is hard to legally convict the offender, because at the time of committing the material element that directly resulted to the death or injury of the victim, the person charged lacked the necessary psychological control over his/her action (first example) or seemed to have the right to selfdefense (second example)[25]. This is acceptable in a case without a prior fault, but it is not when and where there is a prior fault [26]. Such examples show that the usual approach to coincidence, namely, absolutism, must be avoided, and instead resort to our "relativistic" view which does not completely reject coincidence, but remains faithful to it in a more practicable way. In fact, the aim is not to punish those whose criminal behavior is not coincided with their intentions, but our theory is an attempt to show the existence of a relationship between the act and the perpetrator's intention, with a

21. Murray, "Prior fault", 8-11; Baird, Criminal law, 68 $\& 76$.

22. Brandon, A Review of the UK Penal Code, 156.

${ }^{23}$. The two cases are the same as those mentioned in the preceding paragraph, the rule of "Al-emtena" prevents the impunity and, in fact, the criminal liability of the accused. Thus, as you can see, the rule of "prior fault" and its practical application in common law is very similar to the rule of Al-emtena" in Islamic law.

${ }^{24}$. Murray, Op. cit., 165.

- Another example of a prior fault that deprives a defendant from the defense of necessity is where a person deliberately brings about a state of danger, and then commits a crime to escape the danger.

- Cheong, Yeo \& Hor, Criminal law for the $21^{\text {st }}$ century, 332.

${ }^{25}$. Alan Reed et al., General defences in criminal law, 37.

26. Yannoulidis, Mental state defences in criminal law, 104. 
realistic view of coincidence where there is, in fact, a relation between the present intention and the offender's previous faulty behavior [27].

Our relative approach to the principle of coincidence supports the fact that the aim of legal rules is to include as much cases as possible. In other words, taking into consideration the failure of the usual absolute approach to the principle in such cases mentioned above, it is necessary to look for a single solution to cover all cases in a single logical reading of the principle of coincidence which is offered by our relative approach. Accordingly, in justifying responsibility for the offender in cases of this kind, the principle should be based on "prior fault". In general, "prior fault" refers to responsibility for the subsequent conduct, for which the doer is not responsible at first glance, but s/he is found responsible when the case is analyzed in depth and found that his/her prior fault is to be blamed for the criminal event [28]. Thus, standing on "prior fault" prevents the immunity of a criminal from the punishment created by his/her own fault [29].

This theory has been used by some Iranian lawyers as an exception to the absolute view of the principle of coincidence between actus reus and mens rea, where they attempt to interpret Article 154 of the Islamic Penal Code in accordance with the absolute view of the principle, stressing on "past intention to commit a crime or prior fault" to justify punishing a drunk who drinks to commit homicide with a view to escape punishment [30]. These lawyers believe that the legislator in article 154 of the Islamic Penal Code seems to be blaming and punishing this person for his/her "prior fault", that is connecting the previous intention of the offender to his/her subsequent criminal behavior. In other words, a person who becomes drunk with a view to committing a crime, although $\mathrm{s} / \mathrm{he}$ is not willing at the time of committing the crime, s/he is accountable for his/her previous will. Therefore, it is as if the crime was committed while offender's behavior and his/her intention were coincided [31]. Hence, the criterion of "prior fault" is a proper and legally justifiable criterion that supports our theory of relative reading of the principle of coincidence.

Theory of "previous fault" is used when and where mental element precedes material element; but if material element precedes mental element, then the

27 . Ibid., 38-39.

28. Sistare, Responsibility and Criminal Liability, 159; Ormerod \& Laird, Criminal law, 156.

${ }^{29}$. Horder, Ashworth's principles of criminal law, 110.

30. zeraat, Special Criminal law (1), 139-138; Jafari, "Reflection on the nature and scope of will in the realization of criminal responsibility", 134.

31. Sepahvand, Special Criminal Laws (1) (Crimes against Individuals), 84. theory of "continuing act" is applicable. This also strengthens our theory of relativism of coincidence between the elements. "Continuing act" is a concept that courts are inclined to develop in order to ensure that they remain in the axiom of the principle of coincidence [32] when and where the offender commits the material element of the crime in a moment (without the necessary mental element), but at another moment, s/he has the necessary mental element. In fact, in this case, we are faced with the primacy of the material element on the mental element [33].

The important condition to apply the theory of "continuing act" is that the forbidden act or material element of the crime in question must be continuous, not the result. Therefore, if the material element finishes, although its results continue, the subsequent mental element cannot be said to coincide with the material element and make it a crime. For example, if (A) accidentally hits (B) in a car accident, as the result of which (B) is injured and died after a while, and (A) becomes happy that $(\mathrm{B})$ is dead. Then the death of $(\mathrm{B})$ will not be murder because the death has been completed before the wish of the accused for the death of B [34]. It should also be noted that the theory of "continuing act" is different from a continuing offence. The concept of continuing offence is that a crime continues with all its components, that is, material and mental elements over time; but a "continuing act" is merely an act that continues in a period of time[35].

Some lawyers use the theory of "duty to act or Statutory duty" to justify criminal responsibility in such cases, rather than using "continuing act" theory; hence, when the offender, despite "duty to act" doesn`t make any attempt to stop his/her illegal behavior, then it is deduced that material and mental elements of the offense coincide, although such coincidence cannot presumed under absolute view of coincidence. The principle of "duty to act" is applied in cases where for example a person (A) accidentally does an illegal act but then deliberately or consciously does not seize to act[36]. For a better explanation of this principle and its relation to the theory of "continuing act", one can refer to the case, which is described in more detail below.

The theory of "duty to act" further proves our theory of relativism of coincidence between elements as is exemplified by cases in common law. This is

32. Cross, Criminal law and Criminal justice An Introduction, 35.

33. Molan, Cases and Materials on Criminal Law, 265; Storey \& Lidbury, Criminal law, 18.

${ }^{34}$. Allen, Textbook onCriminal law, 54.

${ }^{35}$. Estrada, Criminal law: made easy for students, bar examinees \& practitioners, 258.

${ }^{36}$. Loveless, Criminal Law (Text, Cases and Materials), 53; Hogan \& Smith, Criminal Law, 49-50. 
comparable with the issue of "committing act crimes through omission" as is stated by the Iranian jurists. Some criminal lawyer[ 37 ] under the topic of "Committing act Crimes through omission" argue that the responsibility for someone who omit to act is due to the fact that he had the "duty to act" but does not fulfill his duty[38].

To support further the argument of this paper that relative coincidence is consolidated by the rule of "single sequence of events", the following questions and answers from five contemporary Iranian great Ayatollas is very illuminating.

The question: "A, In order to kill $\mathrm{B}$, throws a blow at his head, which, as a result, becomes unconscious, while a thinks B is dead, throws him into the water to get rid of his body and he dies as a result of drowning. Does this constitute murder or quasiintentional homicide or unintentional homicide"?

Answer: "In the case of the question the killing is murder and must be punished by Qisas"[39]. To summarize the discussion, in the case of doubt whether the two elements of a crime coincide, different justifications have been offered by the Iranian and English law scholars, all of which allude to one single fact that coincidence is not an absolute concept which strongly support our relative account of coincidence. In cases where mental element of an offence comes before material element, the theory of "prior fault" has been used to justify coincidence, and where mens rea is formed later than the material element, the rule of "a single sequence of events" and its associated theories of "duty to act" and "continuous act", provides enough room to justify coincidence of elements [40]. In other words, our relative view of coincidence puts both reasoning in context and concludes that in any given offence in which its material and mental elements coincide at least at one point in the course of its commission, then it is safe to state that the rule of coincidence has been met.

It would now seem desirable to look into the judicial precedent of the common law and Iranian system to see how much our theory of relative

\footnotetext{
37. Mir Mohammad Sadeghi, Op. cit., 47-28.

${ }^{38}$. Najafi, Volume 42, Op.cit, 24; Amoli, Al-Rozate AlBahiah Fi Sharh Al-Lomate Al-Dameshghiah, 152; Haeri, Riaz Al-Masael, 543; Ardebili, Majma AlFaedeh v Al-Borhan Fi Sharh Ershad Al-Azhan, 258; Amoli, Meftah al-Kerama Fi Sharh Al-Ghavaed AlAlameh, 521.

39. Madani Tabrizi, Book of Al-Ghaza, 221. Ayatollah Makarem Shirazi; Ayatollah Bayt Zanjani; Ayatullah Safi Golpayegani; Ayatollah Hashemi Shahroudi. ${ }^{40}$. Herring, Criminal Law, 178.
}

coincidence is informed by the rulings of the judicial courts.

\section{Judicial Cases}

The famous case that is based on the "prior fault" theory in the common law is the case of Thabo Meli v R. In this case, the defendants killed the victim in a pre-prepared program by several blows on his head. Believing he was dead, the defendants then threw him down the cliffs to get rid of the corpse. Evidence showed that the death of the victim was not due to the blows that struck him, but he died from the fall of the rock. The fact, in this case, is that at the time of the material element (the moment of rocketing), the defendants lack the mental element although they have had the mental element earlier and at the moment of the victim's knock on the head [41].

In this case, the majority of the royal council considered the incident a crime. Justifying their ruling, they stated that mere ignorance and misconception of the perpetrators of the time of murder cannot lead to their escape from criminal responsibility for the murder and also cannot divide the continuous actions taken in line with a predetermined plan, but the whole process is one single act[42]. At the time of the commencement of performing the material element of the crime, the defendants had the necessary mental element for it, so the mental element and the material element were at the same time. According to this theory, if there is an explicit intention at one point in the course of committing a crime, it does not make any difference that at which part the death of the victim took place[43].

The English court of appeal has generalized the logic for conviction in Thabo Meli, in cases where there is no previous planning and design to kill or a wrong belief that the victim is a corpse. In the case of Le Brun $\mathrm{v} \mathrm{R}$, the accused directed a blow at his wife causing her to fall on the ground. The defendant then, drags his wife, who refuses to go home, in an attempt to hide his criminal acts. In the course of dragging the wife, her head hits the ground and dies as a result. The court believes that the possibility of sentencing the accused (husband) to manslaughter exists since the striking and dragging the wife is a set of single acts. In fact, in cases of prior fault in determining the type of the offence as to whether it is intentional or unintentional, most judges take the view that it should be the primary intention to consider whether the offence is intentional or accidental [44]. The important point, in

\footnotetext{
41. Martin \& Storey, Unlocking Criminal law, 77.

42. Anyangwe, Criminal law: The general part, 240; Clarkson \& Keating, Criminal Law, 18; Elite \& Queen, Criminal law, 79-78.

43. Herring, Criminal Law, 177; Simester \& Sullivan, Op. cit., 169.

${ }^{44}$. Martin \& Storey, Op. cit., 77.
} 
this case, to convict the defendant is that he drags the wife to hide what he has done. However, if the dragging was not done to hide his criminal acts, but to take his wife for medical care, the court would not count his actions as a single act and does not convict him to manslaughter because in this case, the causal relationship between the offender`s act and his primary intention is disconnected; thus it is not covered by rule of "a single sequence of events"[45].

Our search of the rule of "single sequence of events" in Iranian sources [46] and related sites [47], as well as questions from Iranian scholars and judges [48]

${ }^{45}$. Hogan \& Smith, Op. cit., 35.

- For more information on this, see the (R.V. Church (1965)) case.

- Herring, criminal law Concentrate, 36.

${ }^{46}$. Iran's judicial review books such as:

- Judicial Training Deputy, Iran's Judiciary in relation to the Penal Courts of the Province; Judicial Training Deputy, Iran's Judiciary in relation to the Appeals Court of the State (Criminal); Research Institute for Extracting and Study of Judicial Precedent, Collection of Judicial Appeals of the Appeal Courts of the Provincial (Penal Code) (1395- 1390); Judicial Training Deputy, Iran's judicial procedure in relation to the criminal Branches of Supreme Court of the country; Judicial Training Deputy, The description and analysis of judicial decisions in criminal matters (murder); Judicial Training Deputy, Iran's judicial process in relation to public criminal courts; Judicial Training and Researching Deputy, Collection of jurisprudencevotes in criminal matters; Judicial Training Deputy, Elected votes of Iranian judicial authorities; Reshadati, Selection of Criminal Judgments for murder-manslaughter.

47 . "Research Institute of the Judiciary power"

48. Mr. Aziz Mohammadi (former head of Branch 71 of Tehran Province Criminal Court), Mr. Motamedi (former head of Branch 74 of Tehran Province Criminal Court), Mr. Rezaii (Prosecutor of Firoozkooh), Mr. Reshadati (Supreme Court Judge) Mr. Jafarzadeh (Supreme Court Judge).

Many of these judges believe that in such cases, the accused is intending to commit murder and it is not important that at one moment in the process of commission the intention was missing, and at another moment there was intention; because the defendant intended to destroy a human being (the victim) and that person has been destroyed. Therefore, it would not make any difference which of the two acts of the accused led to the death of the victim. In other words, in this case, they compare the subject with a mistake in identity, and believe that, as the mistake in identity is not important, and it is important that the person intends to kill a human being, so is in such cases because, in indicate that similar cases to those mentioned earlier in common law exists in Iranian system and similar rulings have been made by courts, although justifications for such rulings have not always been clearly mentioned by judges and law scholars.

Judgment No. 251-17/8/1376 issued by Tehran Province Criminal Court, reads that the accused (Valiollah), as a result of a failed love story with the wife of the victim (Asghar), decides to take his life in revenge. With two of his friends, Valiollah batters the victim to death. Then, in order to get rid of the body of the victim and escape to be punished for murder, makes up an accident in which the body is burnt in flames of gasoline leakage from the victim's motorcycle. Forensic examination of the body showed that the cause of death was not suffocation, choking or poisoning, but it caused by $95 \%$ burning of the head, face, hands, feet and abdomen of the victim. So the defendant was convicted to murder, but he denied it and appealed to the Supreme Court. Rejecting the appeal, Branch 11 of the Supreme Court has ruled (5-16/4/1377) that taking together the result of forensic examination, the report of the officer of technical expert on car accidents which indicates that the burning of the victim and his motorcycle was not due to a real accident, testimony of the witnesses and statements of the victim's wife, as well as the contradictory statements of the accused at various stages of the trial and, according to the reasons behind the crime scene, it is clear that the perpetrator (Asghar) has deliberately committed murder[49].

In this case, as in Thabo Meli V R 1954, the defendant, when attempted to get rid of the supposed dead body of the victim, had no intention to kill although he was intending to kill at the time when battered the victim, thus material and mental elements were not coincided in its absolute meaning of the term, coincidence. Yet, he was convicted of murder.

Another judgment in this regard is verdict number 14 dated $6 / 9 / 1380$ by the 19 th branch of the Supreme Court [50] in which, unlike the first one, the defendant was acquitted of murder and its legal punishment [51]. Facts of the case shows that the victim

any case, a human being dies. Other judges resort to similar reasoning to the lawyers and judges of common law who believe that the whole behavior of the defendant has to be considered from the moment of the blow to the moment when measures taken to get rid of the body of the victim.

49. Judicial Training Deputy, Iran's Judicial Precedent in relation to the Criminal Courts of the Province, 153161.

${ }^{50}$.Ibid., 162-237.

51 . Other Judgments of Iranian courts similar to this are number $85-4 / 3 / 1345$ issued by Branch 2 of the Sixth 
(Majid) was suffocated by one of the defendants (Samad) and the body was then thrown to a water pool near the site of the killing by him and his friend (Karim) who was told by Samad that it was a corpse. Forensic report, however, points out that the examination of the body indicates there was no sign of strangulation, poisoning and burning, but the cause of death was drowning in water.

In this case, although no mention has been made of the principle of coincidence between material and spiritual elements, it seems that the Supreme Court judges had in mind that there was no coincidence between elements in its absolute meaning of the term. Indeed, given the fact that the cause of death was drowning and not the blows, on the one hand, and when the perpetrators tried to throw the slain into the water, they thought they were dealing with a corpse, on the other, therefore in our view coincidence between the two material and spiritual elements in its relative meaning is present and acquittal verdict does not seem to be justifiable.

Another notable case in this regard which seems to be very similar to the case of Le Brun, in common law, is verdict No. 12, 12/9/1384 issued by Branch 71 of Tehran Province Criminal Court[52]. In this case, the defendant (Jamal) because of personal matters decides to kill the victim (Javad) and hits him by car and then by several punches so as he falls on the ground hitting his head against the edge of pavement and becomes unconscious because of serious head injuries. The defendant (Jamal) assumes the victim is dead, takes him inside his car and throws the body by the edge of the road somewhere between Tehran and Shahriar. Forensic examination shows that the death of the victim was not caused by car hit or punches but it was due to obstruction of the victim respiratory tract leading to his suffocation while he was unconscious and improperly placed in the back seat of the defendant car.

The opinion of the majority of Branch 71 of Tehran Criminal Court is that the killing was not murder, but it was quasi intentional. However, the opinion of the minority of the judges of this court is that, given the fact that the defendant was intending to kill the victim during the long time and distance between the place of conflict and the death point, mental element for murder is present in the whole process of the accused behavior. Branch 37 of the Supreme Court, however, does not confirm the decision on the grounds that the killing is not manslaughter, so the case is referred to Branch 72 of Tehran Criminal court for reconsideration.

District Court and No. 68 dated 13/3/1345 issued by

52. Similar to this judgment, is No. 132-11 / 10/1384 Branch 2 of the Central Criminal Court. issued by this Criminal Court.

The majority of judges of Branch 72 of Tehran Provincial Criminal Court in their judgment (226$8 / 8 / 1385$ ) similar to that of Branch 71 , took the view that the killing was not murder, considering that according to the forensic examination the death was not due to blows by the defendant or his car but the death was due to the improper placement of the victim in the back seat of the car. The minority group of judges of this court, however, believed that the killing was murder, because what the defendant has done after the collision of his car with the victim has resulted in the death of the victim during which the accused was still intending to kill him. Therefore, since the actions taken by the accused from the first to the last point when the death of the victim occurs, leaves no room for doubt that he was intending to kill the victim from the beginning to the end of the process, a sentence of murder has to be given. Branch 37 of the Supreme Court quashes the judgment and returns it to the court for reconsideration [53].

It seems obvious that in this case, too, the majority of the judges of Branches 71 and 72 of Tehran Criminal Courts have not realized murder due to the lack of coincidence, in its absolute meaning of the term, between the two material and mental elements. By contrast, coincidence does not seem to be a point of issue for the minority who take the whole activities of the accused as a single act. This seems somewhat reminiscent of the rule of "a single sequence of events" in the common law where relative coincidence is applicable and helpful.

The ruling in the above case goes against another ruling $(132-11 / 10 / 84)$ by the same court where it convicts the perpetrator to murder although facts of the case are the same. In this case, a man (sadegh) during a domestic raw with his wife (Parastoo) batters her and throws a TV at her without intention to kill, but then suffocates her because of immense anger. In order to escape conviction and punishment for murder, he beheads the wife and makes the scene for burglary showing she was killed by the thief. Forensic examination shows that she was alive before being beheaded, so beheading by a sharp material is the cause of death during which the husband (Sadegh) was not intending to kill but he presumed he was dealing with a dead body. Despite this, the court convicted him to murder arguing that it does not matter when the wife was killed since both battering and throwing the TV at her by her husband and beheading her, were lethal which, by law, is not required to be intentional.

Bellow, we offer a few charts by which it is attempted to visualize our account of relative coincidence in cases such as those already explained.

53. Aziz Mohammadi, Rahimi \& Yousefi Mahallah, The
murder of the Tehran province penal court, 207-236. murder of the Tehran province penal court, $207-236$.

(C) East African Scholars Publisher, Kenya 
By this we intend to put all such cases in context and solve the discrepancies in an orderly and logical manner compatible with legal rules such as coincidence of material and mental elements.
The first chart shows the distance between 0 and 1 of the time-span of coincidence between the elements.

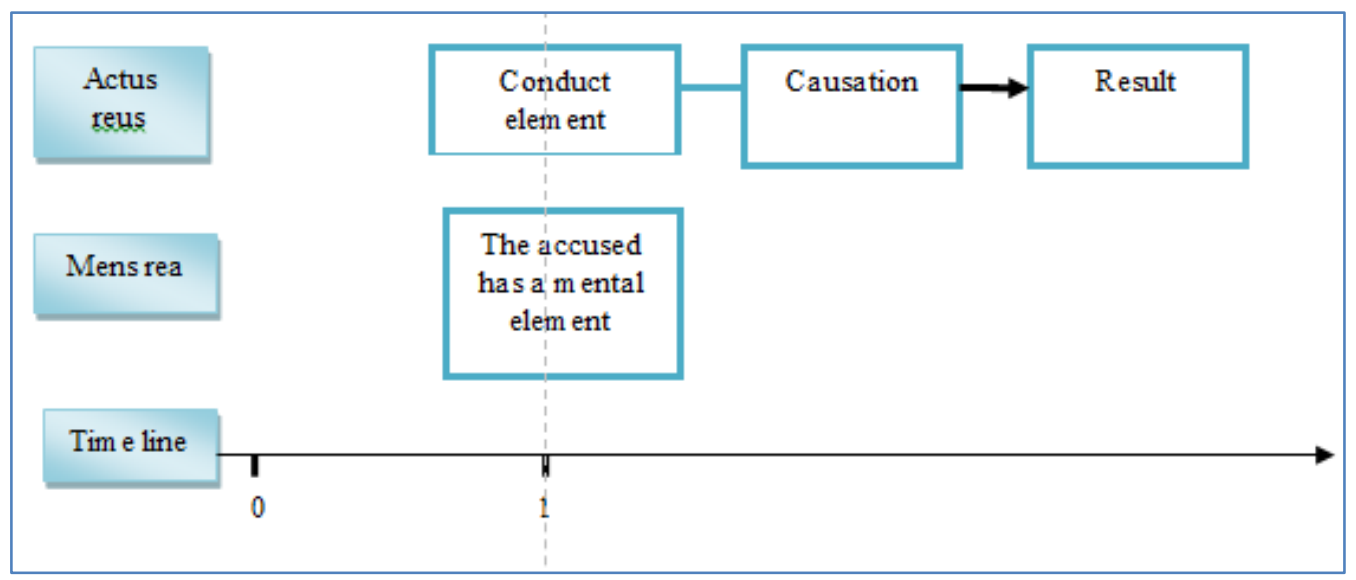

Chart-1: Point 1 coincidence (complete/absolute coincidence between elements)

Point (1) indicates clearest and the most complete or absolute form of coincidence between the elements which is the mere acceptable point in the absolute view of coincidence between the elements [54].

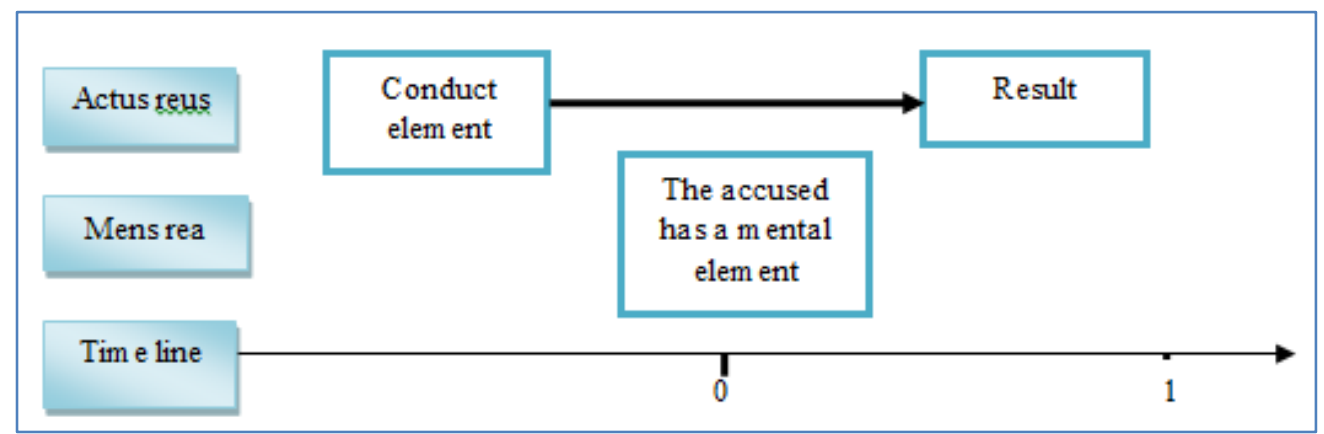

Chart-2: Zero Point of coincidence where material element takes place before mental element and there is no coincidence between elements

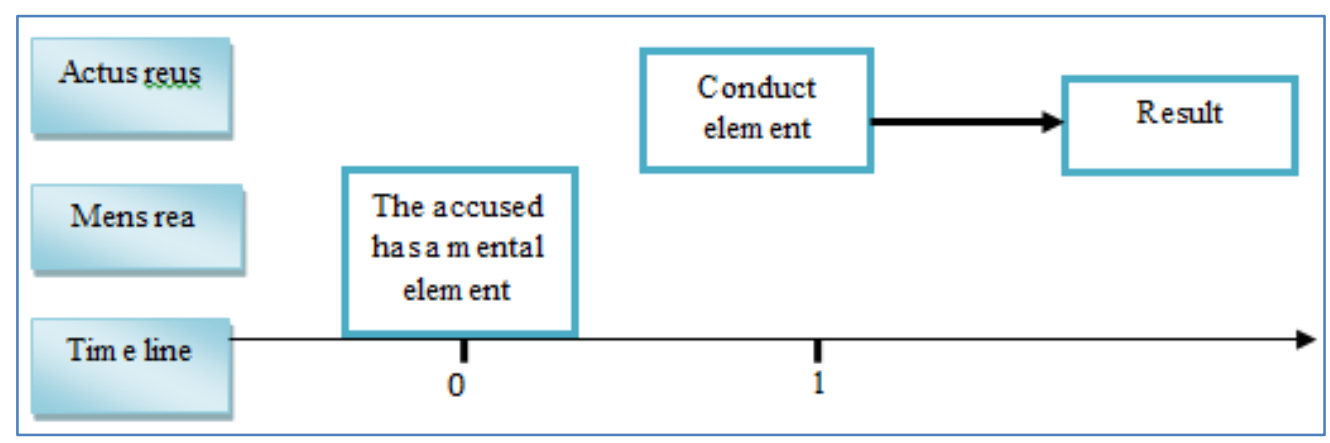

Chart-3: Zero Point of coincidence where mental element occurs before material element and there is no coincidence between elements

${ }^{54}$. Child \& Ormerod, Op. cit., 137 
Based on charts 2 and 3, point zero of coincidence indicates that there is no coincidence, even on the basis of its relative account, between elements of a crime if one of them precedes the other element. This happens where there is no any other influencing factor, such as prior fault or a series of related acts, that can justify coincidence between the two material and mental elements.

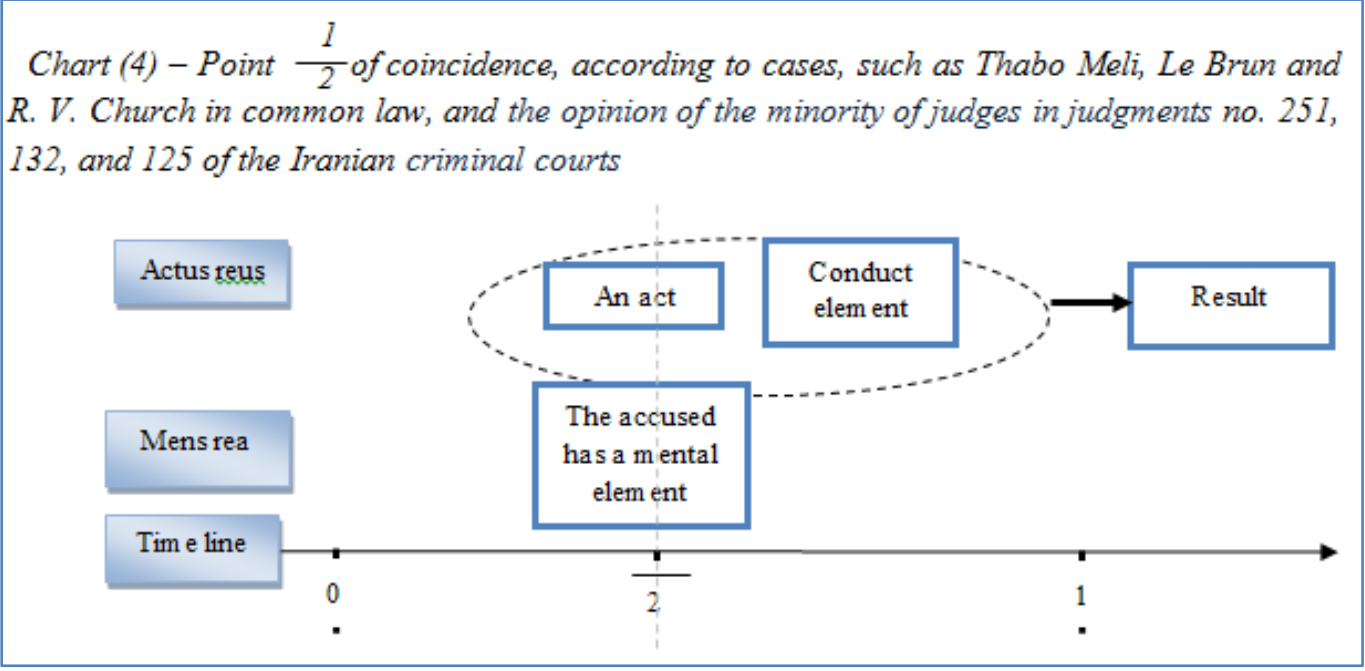

In the cases cited in Chart (4), in fact at the time of doing the act, that is, an assault, the accused has the required mental element, but at the time of the conduct element (whether to burn the corpse or throw it in water or else) leading to the death of the victim does not have the intention to kill. In such cases, the principle of coincidence is met on the basis of the relative account of coincidence and full criminal liability is justified. In other words, it is safe to state that coincidence of elements does not have necessarily to occur at point (1), it can also happen at another point, for example. This is because the concept of coincidence as many other legal concepts is not an absolute or definitive concept which can only matterialise at a particular point (1), but it is a relative and graded concept that stands at any point after 0 to 1 in a timed orbit. Thus, when the conduct element passes point (0) in the time orbit of the crime, coincidence of elements at any point before and at point (1) is complete. The point, which is shown in Fig. 4, has passed point (0) and stopped before point (1) at which the principle of coincidence between the elements comes true.

Judgments no. 85, 68, 115 and majority $\frac{1}{2}$ of judges in judgment no. 125 of the Iranian courts, in which a decree of innocence were passed, indicate that an absolute view of the principle of coincidence between elements have been accepted by judges, that is coincidence takes place only at point (1) of the timing orbit.

Relative account of coincidence can also be traced in cases such as Fagan, as portrayed in figures 5 and 6, where the theory of "continuing act" and "duty to act" have been used to secure criminal liability. In Fagan v Metropolitan Police Commissioner (1969), the defendant parked his car where a police officer ordered him to move his car. While moving his car, the defendant, accidentally drives it on the police officer foot, but when asked to move, the defendant does not follow and switches the engine of his car off. The driver was prosecuted for assaulting the officer in the course of his duty, but the defendant argued that assault is an act crime which needs an act while the facts of the case do not show this. Judges, in this case, argued that the act of driving on the foot and omitting to remove the car were a continuing act. Although the accused was not intending when drove on the foot of the officer, he deliberately allowed the car to remain on her foot despite the fact that the officer requested him to move. In fact, in this case, the material element of the offense of assaulting police officer in the course of her duty begins from the moment the defendant drove on the officer foot until the car is removed and it was enough to be intending at any point of time during this continuing act[55].

Some judges in Fagan case believed that the accused is responsible under the principle of "duty to act"[56 ]. In other words, the defendant who drove his car on the police foot legally had the duty to quickly remove the car and by refusing to do so he has violated the principle of "duty to act", during which he had the required mens rea for assaulting the police officer, as is shown on chart no, 5 bellow[57].

55. Card \& Molloy, Criminal law, 108

56 . Lacey, Wells \& Quick, Reconstructing criminal law, 102.

57. Hogan \& Smith, Op. cit., 49-50.

- To view the judges' various views on the Fagan case:

- Molan, Source Book on Criminal Law, 761-763. 


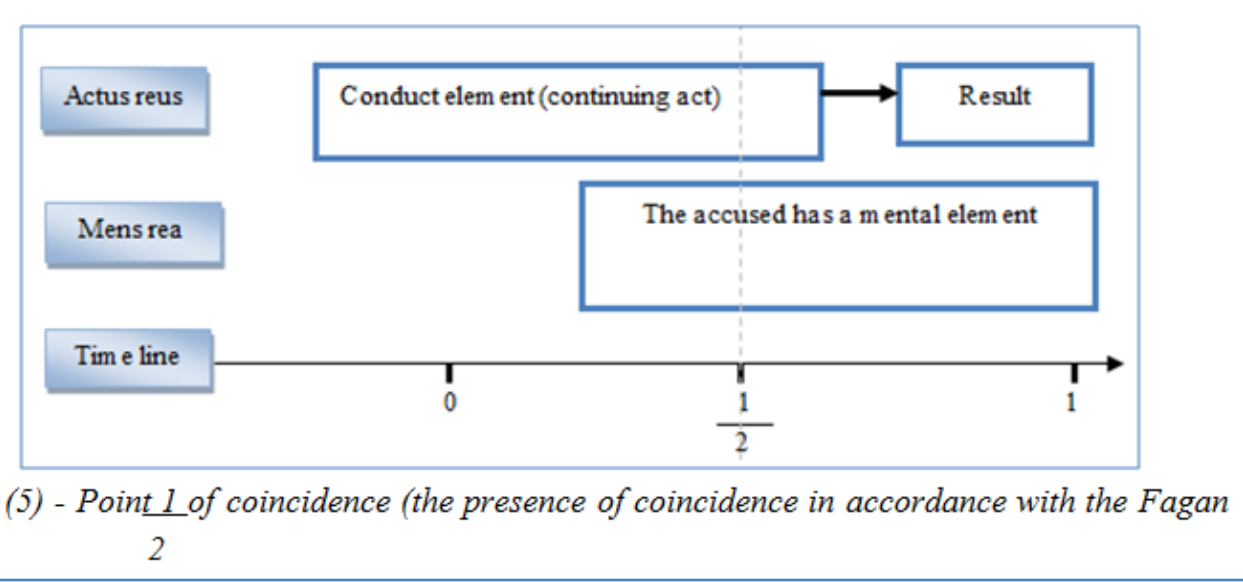

In this case, although at the beginning of the behavior element there is no criminal intention, after some time when the defendant refuses to act, that is to remove his car, he is intending. As shown in the above diagram, coincidence of elements takes place at point.

Another case in common law is the case of $\mathrm{R}$ v Miller (1983) in which the defendant illegally enters a house and lays on a mattress while smoking. He then falls asleep and his cigarette fells on the mattress and causes fire, but he does not take any action to put off the fire and simply walks to another room and goes to sleep. The whole house goes on fire which causes 800 pounds of damage, but the defendant is rescued who was charged with arson according to Articles 1 and 3 of the 1971 Criminal Damage Act. In defense, he argued that his omission not to extinguish the fire that was accidentally started does not constitute the required actus reus of the charge put against him i.e. arson which is an intentional conduct crime. The defense was not accepted by the court and the court arguing that creating a hazard would create a duty to prevent any damage to others. Failure to do so is considered a violation of the duty by the offender in question.

It can be argued that the defendant's behavior in this case is of continuous nature, from the moment he entered the house till the time smoking caused the fire in the house. Therefore, as in the theory of "continuing act", at each stage during the continuation of the conduct element where it can be proved that the mental element existed, according to our account of relative coincidence the defendant is criminally liable. However, the court, in this case, prefers the principle of "duty to act" to the principle of "continuing act" (the principle used in Fagan case) [58].

The theory of "continuing act" and the principle of "duty to act" have also been applied in the case of Kaitamaki (1985). In this case; the Royal Council believed that sexual intercourse is a continuing

\footnotetext{
${ }^{58}$. Ashworth \& Horder, Op. cit, 100.
}

act in relation to the charge of rape[59]. As is shown in chart no. 6, the situation in cases of Miller and Kaitamaki, is that material element of the offenses in question take place prior to mental element in which the court does not resort to the theory of "continuing act" and instead refers to the doctrine of an omission arising from an act to justify coincidence between the elements. In both cases, coincidence takes place at point

No mention has been made of the theory of "continuing act" in Iranian laws. The principle of "duty to act", was only found a formal place in the Islamic Penal Code of 1392. Article 295 of this Code stipulates: "Whenever someone who takes on to do something or is on a particular duty, despite ability to perform it, fails to comply with it causing an offence to someone, shall be liable for an intentional, quasi intentional or unintentional crime thereon".

According to this article, the first condition for imposing criminal responsibility on someone who fails to do what has legally to be done is the existence of a legal duty. This legal duty does not have to derive from criminal law, but it may also be provided by other applicable laws and regulations. By extending the meaning of a "legal duty", it can be said that according to general legal rules, such as the rule of "No harm", when a person does not take a practical step to prevent harm to others may be criminally liable. For instance, if someone deliberately causes a house to go on fire and then realizes that the owner is sleeping in the house but does not take any action to save the life of the owner despite the ability to do so, s/he could be considered a murderer, if intention to kill is proven. Obviously, if the intention to kill is not found, the offence will be unintentional.

Criminal liability would seem more difficult in cases where the initial risk is unintentional. For instance, a driver negligently or carelessly hits a

59. Quinn, Criminal law Ireland, 41; Monghan, Criminal Law, 76; Padfield, Criminal law, 292. 
pedestrian. The driver rushes to help the injured person, but when realizes that the injured is his/her creditor, leaves him/her who later dies because of bleeding (not because of the accident). Applying the reasoning used in English law in the case of Fagan v. Police Officer, it would not seem unjustified to consider such a death as murder if the driver's intention to kill is proven.

\section{CONCLUSION}

The main content of our argument is summarized in the following chart.
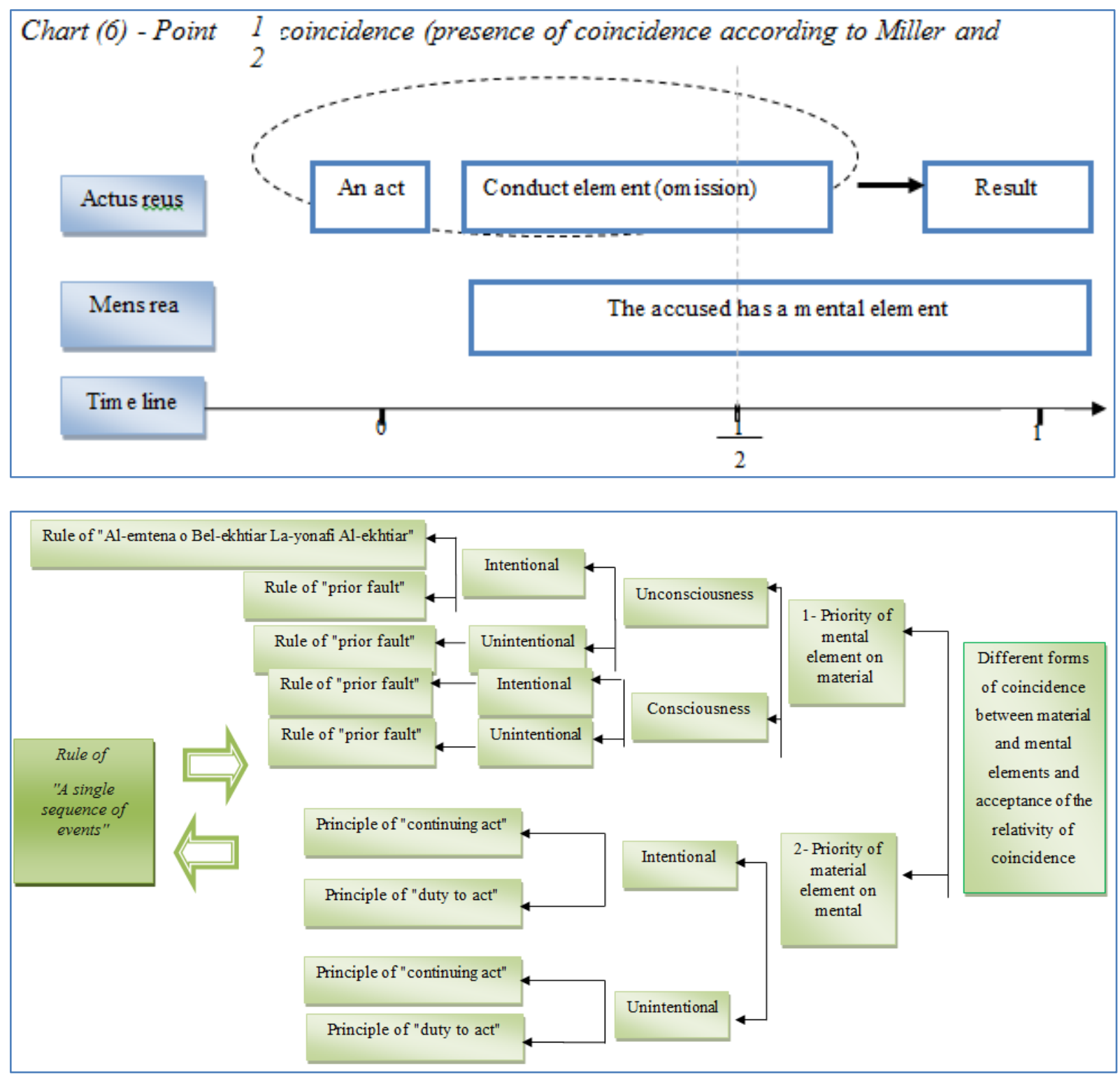

Chart-7: Different forms of coincidence relativity

In all cases where coincidence in its "absolute account" is difficult to find, the principle of "a single sequence of events" provides a strong ground for our "relative account" of coincidence. It is contended that the Islamic rule of "al-Emtena" merely covers some of those cases that fall under the principle. The same is true about other rules and theories in the English common law, including the theory of "prior fault", "continuous act", and "duty to act". In other words, the Islamic rule of "al-Emtena" and similar rules in English common law fall under the rule of "a single sequence of events" which together justify our claim of "relative" coincidence. A vital point to be considered here is that the subject of all cases dealt with under this rule is crimes against the person, but our claim is that it would also be possible and very useful to be applied in cases of other crimes. It seems, therefore, desirable for both systems, particularly Iranian system, to provide for a comprehensible response to the problem by way of legislation. 


\section{The legislation would have to include the following main points}

- In all crimes requiring both mental and physical elements, they have to coincide.

- Coincidence in one part of the physical element is sufficient, as in a case where someone deliberately drinks or makes $\mathrm{him} /$ herself unconscious or goes to sleep in order to commit an offence while drunk, unconscious or asleep

- Prior intention coincide with later conduct where the offender imagines that the crime is complete and s/he is trying to clean the scene of his/her crime, but the conduct element of the crime happen to result from his/her attempt when the offender is not intending, as where A kills $\mathrm{B}$ and tries to get rid of the corpse, supposing B is dead, but in fact B is alive and dies as a result of A's conduct to dispose the dead body

- Prior act coincide with later intention where the offender does an act not knowing, at the time of doing, it may lead or give rise to a crime but later finds out that a crime may result from his/her primary action and nevertheless does not try to prevent it from happening or does not discontinue, as where $\mathrm{A}$ takes a mobile phone assuming it is his own phone, but later finds out the phone is not his own, nevertheless he does not return the phone to the owner

\section{A suggestion for purpose of legislation is}

When the conduct element leading to a crime is committed in several stages, even if by lapse of time in between, existence of mental element in one stage is sufficient for full criminal liability, whether the mental element forms before or after conduct element.

Note: Committing a crime while unconscious, drunk or asleep, is considered intentional if the offender drinks, sleeps or goes to state of unconsciousness knowingly and deliberately to commit the crime.

\section{REFERENCES}

1. Aghaei, N. H. (2010). Crimes against individuals. $5^{\text {th }}$ Edition. Tehran: Mizan press, 2010.

2. Aghaei, J.M.H. (2011). General Criminal Law. Volume II. First Edition. Tehran: Jungle Press.

3. Ali, A., Abdul, H. (2013). Criminal law. Volume 1. $5^{\text {th }}$ Edition. Tehran: Ferdowsi press.

4. Allen, J. Michael. (2013). Textbook onCriminal law. $12^{\text {th }}$ Edition. U.K: Oxford University Press.

5. Amoli, Javad ben Mohammad Hosseini. (1998). Meftah al-Kerama Fi Sharh Al-Ghavaed AlAlameh. Volume 10. First Edition. Qom: Islamic Publishers Office affiliated with the Qom Seminary Teachers Society.
6. Amoli , S.S., Zeyn Al-Din ben, A. (1989). AlRozate Al-Bahiah Fi Sharh Al-Lomate AlDameshghiah. Volume 10. First Edition. Qom: Davari Bookstore Press.

7. Anyangwe, C. (2015). Criminal law: The general part. Cameroon: Langaa RPCIG publisher.

8. Ardebili, M. A. (2013). General criminal law. Volume 1. 32 ${ }^{\text {th }}$ Edition. Tehran: Mizan Press.

9. Ardebili, Ahmad ben Mohammad. (1982). Majma Al-Faedeh v Al-Borhan Fi Sharh Ershad Al-Azhan. Volume 14. First Edition. Qom: Islamic Publishers Office affiliated with the Qom Seminary Teachers Society.

10. Ashworth, A., \& Jermy, H. (2013). Principles of criminal law. $7^{\text {th }}$ Edition. U.K: Oxford university press.

11. Aziz, M., Nour, A., Hassan, R., \& Ibrahim, Y. M. (2013). The murder of the Tehran province penal court. Volume $1.2^{\text {nd }}$ edition. Tehran: Jungle Press.

12. Baird, N. (2015). Criminal law. $10^{\text {th }}$ Edition. London \& New York: Routledge press.

13. Brandon, S. (1997). A Review of the UK Penal Code. Translation and Description: Hossein Mir Mohammad Sadeghi. First Edition. Tehran: Hoghoghdan Press.

14. Card, R., \& Jill, M. (2016). Criminal law. $22^{\text {th }}$ Edition. U.K: Oxford university press.

15. Child, John, David Ormerod \& Hogan Smith. ormerod's Essential of criminal law. $2^{\text {nd }}$ Edition. U.K: Oxford University press.

16. Cheong, C., Stanley, Y., \& Michael, H. (2013). Criminal law for the 21 st century. First Edition. Singapore: Academy Publishing.

17. Clarkson, C.M.V., \& Keating, H.M. (2014). Criminal Law. $8^{\text {th }}$ Edition. U.K: Sweet \& Maxwell Publisher.

18. Cryer, R., Hakan, F., Darry, R., \& Elizabeth, W. (2010). An introduction to international criminal law and procedure. $2^{\text {nd }}$ Edition. New York: Cambridge university press.

19. Cross, N. (2010). Criminal law and Criminal justice An Introduction. First Edition. New York: SAGE publications Ltd.

20. Judicial, T. D. (2009). Judicial Procedure of Iran in relation to the Penal Courts of the Province. Volume I, II and III. $2^{\text {nd }}$ edition. Tehran: Jungle Press.

21. Judicial Training Deputy. Iran's Judicial Procedure in relation to the Provincial Court of Appeal (Criminal). $2^{\text {nd }}$ edition. Tehran: Jungle Press, 2009.

22. Judicial, T. D. (2015). Iran's judicial procedure in relation to the criminal Branches of Supreme Court of the country. First Edition. Tehran: Jungle Press.

23. Judicial, T.D. (2008). The description and analysis of judicial decisions in criminal matters (murder). Volume 1. First Edition. Qom: Ghaza Press.

24. Judicial, Training Deputy. (2009). Iran's judicial process in relation to public criminal courts. Volumes 1 to $8.2^{\text {nd }}$ Edition. Tehran: Jungle Press. 
25. Judicial Training and Researching Deputy (Jurisprudence Research Center). (2002). Collection of jurisprudencevotes in criminal matters. Volumes 1-4. First \& Second Edition. Tehran: Publishing Department of Judiciary Training and Research, 2002 \& 2003.

26. Judicial Training Deputy. (2007). Elected votes of Iranian judicial authorities. First Edition. Qom: Ghaza Press.

27. Elite, C., \& Francis, Q. (2008). Criminal law. Translated: Ava Wahidi Nuwayi and Nastaran Ghazanfari. First Edition. Tehran: Mizan Press.

28. Elliott. (2000). Catherine \& Frances Quinn. Criminal Law, $3^{\text {rd }}$ Edition. London: Longman Press.

29. Eshtehardi, A.P. (1996). Madark Al Orvah. Volume 10. First Edition. Tehran: Dar Al-Asvah Leltabate v Al Nashr Press.

30. Estrada, C. A. (2008). Criminal law: made easy for students, bar examinees \& practitioners. Manila: Published \& Distributed Book Store.

31. Findlay, M. (2006). Criminal law: problems in context. $2^{\text {nd }}$ Edition. U.K: Oxford university press.

32. Gapanchi, H. (1996). "The Qisas of the drunken killer in Islamic Jurisprudence and Islamic Penal Code". Journal The views of the judiciary law 2: 129-154.

33. Haeri, Ali ben Mohammad, T. Riaz Al-Masael. Volume II. First Edition. Qom: Publication of the Aal-o- Al-beit Institute, No date.

34. Herring, J. (2006). Criminal Law. $2^{\text {nd }}$ Edition. U.K: Oxford University Press.

35. Herring, J. (2016). Criminal law Concentrate. $5^{\text {th }}$ Edition. U.K: Oxford university press.

36. Horder, J. (2016). Ashworth's principles of criminal law. $8^{\text {th }}$ Edition. London: Oxford university press.

37. Hogan, B., \& John, S. (2011). Criminal Law. $13^{\text {th }}$ Edition. U.K: Butterworth Publisher, 2011.

38. Ismailian, Ahmad. "Drunk Qisas in Imam jurisprudence, relying on Kheoi's researcher". Scientific magazine of scholars of the Jurisprudence Specialist Training Center 1 (2014): 30-75.

39. Jafari, M. (2016). "Reflection on the nature and scope of will in the realization of criminal responsibility". Journal of Criminal Law Research, $15 ; 121-141$.

40. Khansari, Ahmad, Y. (1984). Jame Al-Mardak Fi Sharh Al-Mokhtaser Ah-Manafe. Volume 6. $2^{\text {nd }}$ Edition. Qom: Ismailian Institute.

41. Khoei, A. (1976). Fundamentals of Takmelah Al Menhaj. Volume 1. Najaf: Matbea Al Adab Press.

42. Lacey, N., Celia, W., \& Oliver, Q. (2010). Reconstructing criminal law $.4^{\text {th }}$ Edition. New York: Cambridge Press.

43. Loveless, J. (2016). Criminal Law (Text, Cases and Materials). $5^{\text {th }}$ Edition. U.K: Oxford University Press.
44. Madani, T. Y. (1994). Book of Al-Ghaza. Qom: Ayatollah Yousef Madani Tabrizi Publishing.

45. Marashi, N., Shahab, al-Din. (1994). Al-Qasas Ali Zoe Al-Quran and Al-Sunnah. Volume 1. First Edition. Qom: Ayatollah Marashi Najafi Press.

46. Makaram, Shirazi, N. (2006). New Esftaat. Volume 2. $2^{\text {nd }}$ Edition. Qom: Imam Ali ben Abi Talib School press.

47. Madani, K., Haj, A, R. (1989). Book of Al-Qasas Lel Foghaha $v$ Al-Khawas. $2^{\text {nd }}$ Edition. Qom: Islami publishing office affiliated with the community of teachers of the Qom Seminary.

48. Martin, J., \& Tony, S. (2015). Unlocking Criminal law. $5^{\text {th }}$ Edition. London \& New York: Routledge press.

49. Mir, M. S., Hossein. (2017). Crimes against individuals. $24^{\text {th }}$ Edition. Tehran: Mizan Press.

50. Movahedi, L., Mohammad, F. (2004). Comprehensive Issues. Volume 2. $11^{\text {th }}$ Edition. Qom: Amir Qalam Press.

51. Mostafavi, M.K. (2000). Maate ghaedate Feghieh. $4^{\text {th }}$ Edition. Qom: Islamic publication affiliated with the community of the teachers of Qom Seminary.

52. Mostafa, M. (1983). Description of the law Al Oghoobat. $10^{\text {th }}$ Edition. Cairo: Matba Al-Jameate Al-Qahrah press.

53. Montazeri, N., Hossein, A. (1988). Islamic government jurisprudential principles. Translator: Mahmoud Salavati and Abou al Shakouri. Volume 4. First Edition. Qom: Kayhan Institute.

54. Mohaghegh, H., Najm, al-Din Jafar ben, H. (1987). Sharaie Al-Islam Fi Masael Al-Halla and AlHaram. Volume 4. $2^{\text {nd }}$ Edition. Qom: The Ismailian Institution.

55. Molan, M. (2008). Cases and Materials on Criminal Law. $4^{\text {th }}$ Edition. USA \& Canada: Cavendish Publishing.

56. Molan, M. (2001). Source Book on Criminal Law. $2^{\text {nd }}$ Edition. USA \& Canada: Cavendish Publishing.

57. Monghan, N. (2018). Criminal Law. $5^{\text {th }}$ Edition. U.K: Oxford University Press.

58. Murray, P. (2014). "Prior fault". The Cambridge Law Journal, 73: 8-11.

59. Najafi, M.H. (1983). Javaher Al-khalam Fi Sharh Shariah Al-Islam. Volume $21 \& 42.7^{\text {th }}$ Edition. Beirut: Dar Ehiaa al-Taras al-Arabi Press.

60. Ormerod, D., \& Karl, L. (2014). Criminal law. $11^{\text {th }}$ Edition. London: Oxford University Press.

61. Padfield, N. (2016). Criminal law. $10^{\text {th }}$ Edition. U.K: Oxford University Press.

62. Quinn, E. Sean. (2009). Criminal law Ireland. $4^{\text {th }}$ Edition. Ireland: Irish law publishing.

63. Rahmani, Z.M. (2008). The rules of jurisprudence (3) the (rule of emergency). Qom: Tebyan Cultural and Information Institute. 
64. Reshadati, J. (2009). Selection of Criminal Judgments for murder- manslaughter. First Edition. Tehran: Paiam Rashedeh Press.

65. Reed, A., Michael, B., Nicola, W., \& Emma, S. (2016). General defences in criminal law. $2^{\text {nd }}$ Edition. New York: Routledge Press.

66. Research Institute for Extracting and Study of Judicial Precedent. (2017). Collection of Judicial Appeals of the Appeal Courts of the Provincial (Penal Code) (1395-1390). First Edition. Tehran: Judiciary Press and Publishing Center, 2017.

67. Sabzevari, A, A. (1992). Mohzzab al-Ahkam, Volume 28, $4^{\text {th }}$ Edition. Qom: Al-Manar Institute.

68. Sepahvand, A.K. (2007). Special Criminal Laws (1) (Crimes against Individuals). First Edition. Tehran: Majd Press.

69. Simester, A. P., \& Sullivan, G.R. (2010). Criminal law: Theory and Doctorin. $4^{\text {th }}$. Edition. U.K: Hart Publisher.
70. Sistare, C. T. (1989). Responsibility and Criminal Liability. First Edition. London: Kulwer Academic Publishers.

71. Storey, T., \& Alan, L. (2009). Criminal law. $5^{\text {th }}$ Edition. New York: Routledge Press, 2009.

72. Tabrizi, Javad ben A. (2005). Tanqih mabani Alahkam - Book of Al-Qasas. $2^{\text {nd }}$ Edition. Qom: Dar Al-Sadighat Al-Shahida Press.

73. Yannoulidis, S. (2016). Mental state defences in criminal law. First Edition. London \& New York: Routledge Press.

74. Yektankhodaei, M. (1997). "Drunkenness and Sleep and anesthesia as Causes of elimination of responsibility". Journal of the Court, 1; 43-49.

75. Zeraat, A. (2015). Special Criminal law (1). $3^{\text {rd }}$ edition. Tehran: Jungle Press, 2015.

76. Judiciary power. "Research Institute of the Judiciary power". Accessed March 1, 2019.

77. http://www.ijri.ir/clientsignup.html

78. http://www.Judgments. Ijri. Ir. 